Artikel

\title{
Implementation of Information Technology Governance Based on CoBIT Framework 5. Case Study: Bureau of Information Systems \& Technology-Buddhi Dharma University
}

$\operatorname{Riki}^{1}$

${ }^{1}$ Sistem Informasi, Universitas Buddhi Dharma, Banten, Indonesia

\begin{tabular}{l}
\hline JEJAK PENGIRIMAN \\
\hline Received: February 6, 2018 \\
Final Revision: February 12, 2018 \\
Available Online: February 27, 2018 \\
KATA KUNCI \\
\hline Audit, Information System, Capability, Level of \\
Maturity \\
KoRESPONDENSI \\
\hline Telepon: 081807834703 \\
E-mail: riki@ubd.ac.id \\
\hline
\end{tabular}

\section{INTRODUCTION}

Utilization of IT in education is very important. IT provides opportunities for transformation and increased business productivity. Implementation of IT requires a considerable cost with the risk of failure is not small, that is if there is interference in IT owned. Implementation of IT in education can be used maximally, therefore needed a proper understanding of the basic concepts of the applicable system, the technology used, the applications used and the management and development of IT systems undertaken.

According to (Indrajit 2006) there are seven roles of IT in education:

\begin{abstract}
A B S T R A K
The purpose of writing, to determine the level of capability in the Bureau of Information Systems \& Technology at Buddhi Dharma University. Analyzing the achievement of its capability level and assisting BSTI in implementing international standardized IT governance. The methodology used is the CoBIT 5 framework as a measure of capability level guidance. The result is that the current level of BSTI capability is 2.027 which means at level 2 (managed process), the standard is at level 3. Conclusion that BSTI has been managed and implemented correctly, although the achievement of the level of capability is still in the middle position due to the lack of competition that forced Buddhi Dharma University to do business development.
\end{abstract}

1. Comes from the awareness that IT is the source of science, the fact is triggered by the connections of various sources and experts of science through the internet.

2. IT function as a tool or means of organizing teaching and learning activities and learning activities. This is related to the increasing number of teachers and lecturers who use various technological tools to assist them in delivering teaching materials.

3. It is a condition where the understanding and skills of utilizing IT in improving the performance of education is a prerequisite of competence that must be owned by a number of main actors of education, 
such as teachers, lecturers, students, researchers, and management of educational institutions. It is within this framework that a number of schools have required both the grantor and the recipient of the knowledge subject to have the minimum competency and expertise in using IT-based equipment.

4. Starting from the IT skills in transforming various forms of organization that rely heavily on physical resources into virtual institutions with the dominance of electronic resources.

5. is the context seen from the educational institution side, where IT is used as technology to assist management or governance of a series of educational activities. Just like a commercial organization like a company, modern educational institutions will implement a digital technology-based administration system such as to conduct a wide range of activities.

6. take the position of the use of various IT applications to analyze the performance of education for the production of a number of decisions and policies for enhancement of institutional performance.

7. is the estuary of the six existing contexts, namely the realization of IT as a modern educational infrastructure. In other words, this digital-based equipment inevitably must be owned or accessed by any educational institution in question.

In this regard, awareness in setting aside a number of financial resources for investment allocation of IT is considered a necessity.

Buddhi Dharma University is one of the educational fields under the Boen Tek Bio Foundation that has been utilizing IT in running academic activities. The increasing number of students and the ongoing competition will demand the right decision and can be achieved if the information obtained quickly and accurately. This is what happens at Buddhi Dharma University, which is information about things on the day that

has been run, can be known at the end of the day and will serve as one of the reference in making decisions for business continuity the next day.

Seeing the importance of information systems within Buddhi Dharma University, IT management also needs to be considered. Buddhi Dharma University should be able to minimize risk by doing IT management properly and correctly.

In this study, we used the CoBIT 5 framework to assess the maturity level of the IT University of Buddhi Dharma management. Through the assessment can be known level of maturity Buddhi Dharma University in running its business.

Based on the description of exposure above, the authors try to formulate the issues to be discussed in this study:

1. How to implement good IT governance according to COBIT Framework 5

2. The extent to which Buddi Dharma University applies IT governance by assessing capability levels

3. Does IT governance meet the capability target targets that are consistent with other Audit Bodies

4. What improvements made by Buddhi Dharma University to improve the role of IT governance in improving performance

The purpose is :

1. Knowing how the implementation of IT governance conducted by Buddhi Dharma University

2. To know the extent of IT performance at Buddi Dharma University by using capability level measurement and CoBIT 5 as reference

3. In order to optimize the use of IT

4. Knowing the steps that must be done by Buddi Dharma University to optimize 
the role of IT governance in improving performance

According to (ISACA 2010) : IT governance is the resposibility of the board of Directors and Executive Management. Its an integral part of enterprise governance and consist of the leadership and organizational stuctures and processes that ensure the organization's IT sustains and extends the organization's strategy and objectives. As already mentioned that IT Governance is the responsibility of the Board of Directors and the executive management of an organization. IT governance is an integral part of corporate management consisting of leadership and organizational structure and processes to ensure the sustainability of the organization's IT and organizational development and organizational goals. (Riki 2017) Measuring the maturity level of the Academic Management System especially on PO and AI Domains, by calculating the level of maturity shows that the existing level of maturity in STMIK Buddhi has not reached the ideal conditions expected.

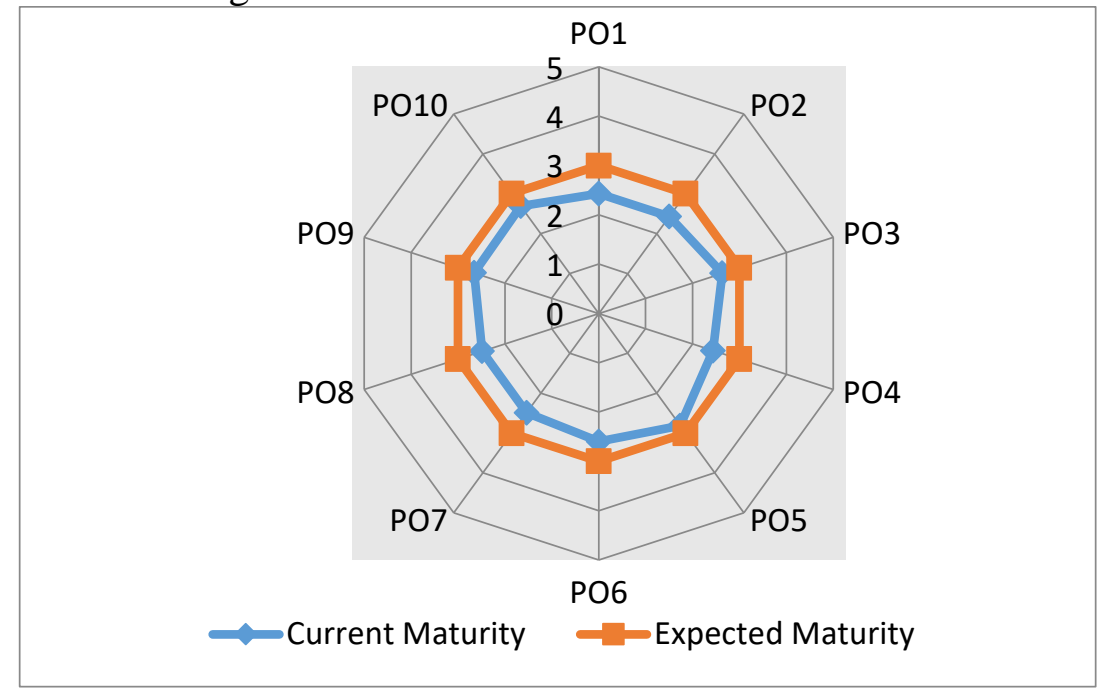

Figure 1. Current maturity level vs Expected maturity level at domain PO

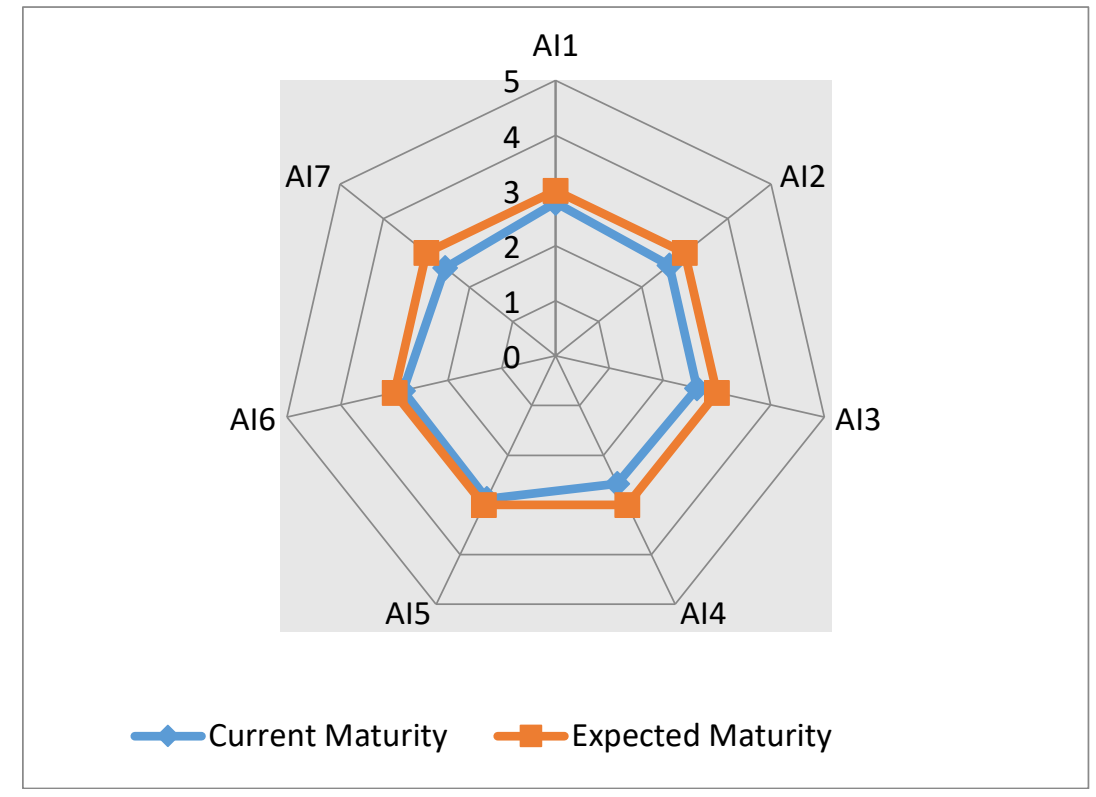

Figure 2. Current maturity level vs Expected maturity level at domain AI 


\section{METHODOLOGY}

The method used in doing this research is qualitative method and using primary and secondary data. Primary data was obtained from interview result from BSTI section while secondary data was obtained from documentation owned by BSTI

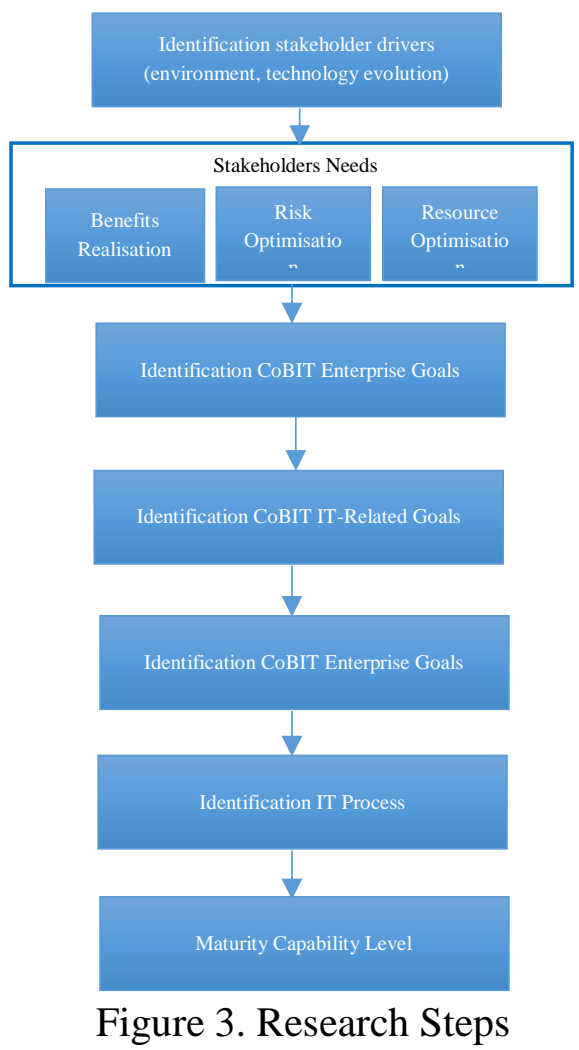

Stage 1: identification of stakeholder drivers, stakeholders affected by the number of controls, such as: strategic changes, changes in business and local regulations and the development of new technologies
Stage 2: CoBIT Enterprise Goals identification, stakeholder needs related to the company's general objectives. It then identifies the objectives of Buddhi Dharma University and then maps to the business objectives according to CoBIT 5 Stage 3: CoBIT IT-Related Goals identification, an analysis of CoBIT enterprise goals with CoBIT IT-Related Goals. CoBIT enterprise goals used are from mapping the business goals of Buddhist University Dharma

Stage 4: Identify IT Process, any ITRelated Goals mapping will produce ITProcess. From each IT-Process serves as a process in measuring the level of capability in the IT governance assessment

Stage 5: Maturity Capability Level, there are 6 levels in process capability assessment. In each assessment at each level are classified into 4 categories as a form of achieving a level of capability. ISACA also explains that fulfillment in a capability level in order to proceed to the next level should reach the category of largely (L) or fully achieved (F)

\begin{tabular}{|c|c|c|}
\hline \multicolumn{3}{|c|}{ Rating Levels } \\
\hline $\mathbf{N}$ & Not Achieved & $\begin{array}{l}0-15 \% \\
\text { achievement }\end{array}$ \\
\hline $\mathbf{P}$ & $\begin{array}{l}\text { Partically } \\
\text { Achieved }\end{array}$ & $\begin{array}{l}15-50 \% \\
\text { achievement }\end{array}$ \\
\hline $\mathbf{L}$ & $\begin{array}{l}\text { Largely } \\
\text { Achieved }\end{array}$ & $\begin{array}{l}50-85 \% \\
\text { achievement }\end{array}$ \\
\hline $\mathbf{F}$ & Fully Achieved & $\begin{array}{l}85-100 \% \\
\text { achievement }\end{array}$ \\
\hline
\end{tabular}




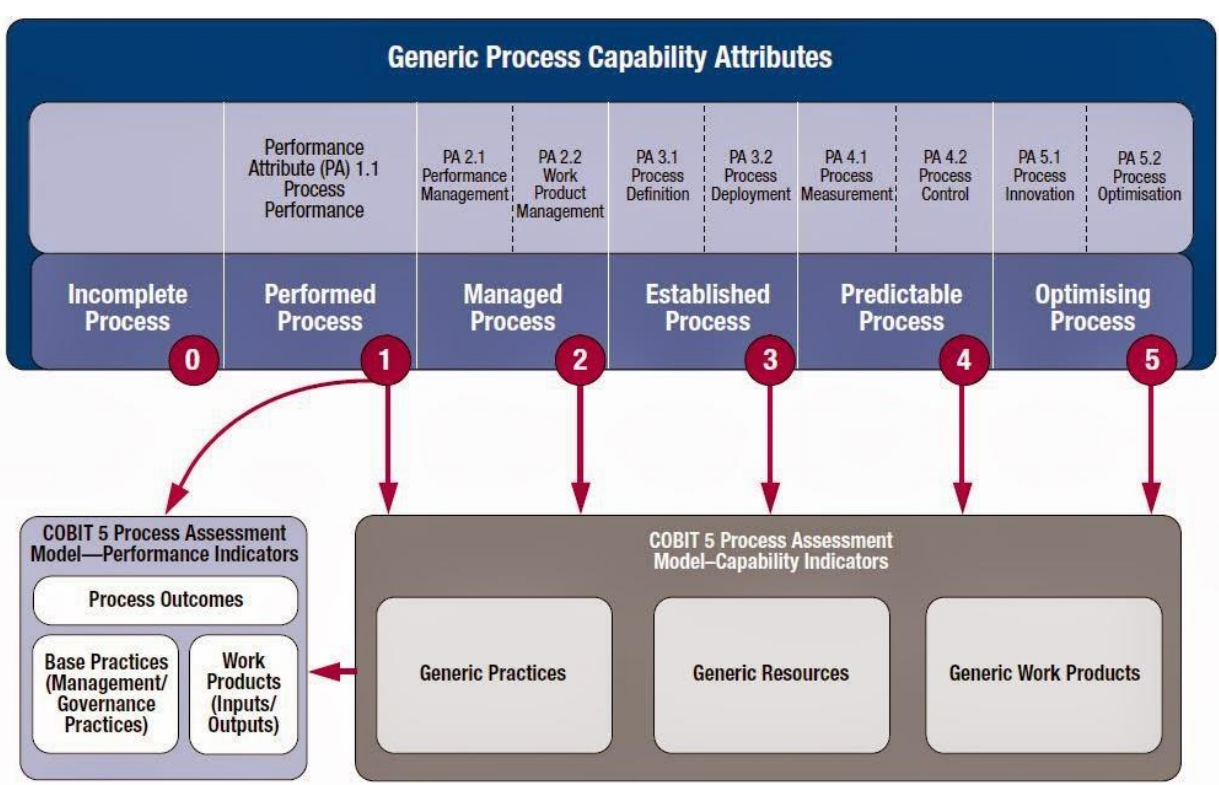

Figure 4. The COBIT 5 Process Capability Model

\section{RESULT AND DISCUSSION}

Based on the results of 37 CoBIT processes, the achievement of the whole process level, as shown below:

\section{Level of Achievement}



Figure 5. Level of Achievement

1. In assessing the capability to know what process will be in the level of capability level, the Buddhi Dharma University explains its objectives into strategic objectives which are then grouped into $4 \mathrm{BSc}$ (Balanced Scorecard) dimensions as follows: expectation and budget utilization

2. The second dimension is the customer which there is a strategic target of Buddhi Dharma University no 7 on improving the institutional quality and management

3. Internal 3rd dimension where there are 
strategic targets of Buddhi Dharma University no 2-7 and 9 regarding business process functions, business program changes, operational and employee productivity, and compliance with internal regulations.

4. The 4th dimension is learning and

Table 1. Mapping Results

\begin{tabular}{|c|c|c|}
\hline $\begin{array}{l}\text { BSc } \\
\text { Dimensio } \\
\text { n }\end{array}$ & $\begin{array}{l}\text { Enterprise } \\
\text { Goals }\end{array}$ & Goal target \\
\hline \multirow[t]{2}{*}{ Finacial } & $\begin{array}{l}\text { Compliance } \\
\text { with } \\
\text { external } \\
\text { laws and } \\
\text { regulations }\end{array}$ & $\begin{array}{l}\text { 1. improve the } \\
\text { effectiveness } \\
\text { of follow-up } \\
\text { of inspection } \\
\text { results and } \\
\text { meet the } \\
\text { expectations } \\
\text { of } \\
\text { stakeholders }\end{array}$ \\
\hline & $\begin{array}{l}\text { Financial } \\
\text { transparenc } \\
\mathrm{y}\end{array}$ & $\begin{array}{l}\text { 10. increase } \\
\text { budget } \\
\text { utilization }\end{array}$ \\
\hline Customer & $\begin{array}{l}\text { Customer } \\
\text { oriented } \\
\text { service } \\
\text { culture }\end{array}$ & $\begin{array}{l}\text { 7. improve } \\
\text { institutional } \\
\text { quality and } \\
\text { management }\end{array}$ \\
\hline \multirow[t]{2}{*}{ Internal } & $\begin{array}{l}\text { Optimisatio } \\
\mathrm{n} \\
\text { business of } \\
\text { process } \\
\text { functionalit } \\
\mathrm{y}\end{array}$ & 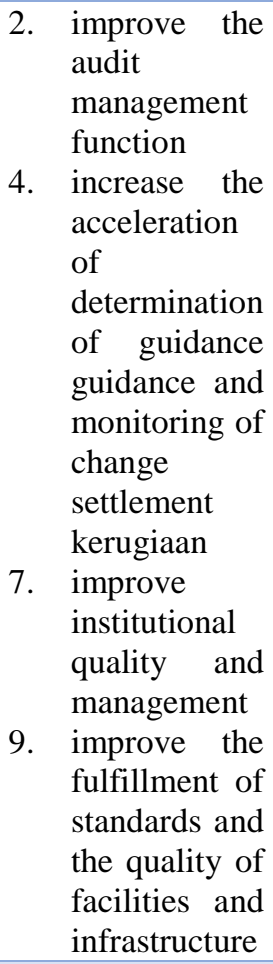 \\
\hline & $\begin{array}{l}\text { Managed } \\
\text { business } \\
\text { change } \\
\text { programmes }\end{array}$ & $\begin{array}{l}\text { 3. improve the } \\
\text { quality of } \\
\text { opinion and } \\
\text { consideration }\end{array}$ \\
\hline
\end{tabular}

growth which there are strategic targets of Buddhi Dharma University no 3 and 8 about the skills and motivation of people and culture to innovate

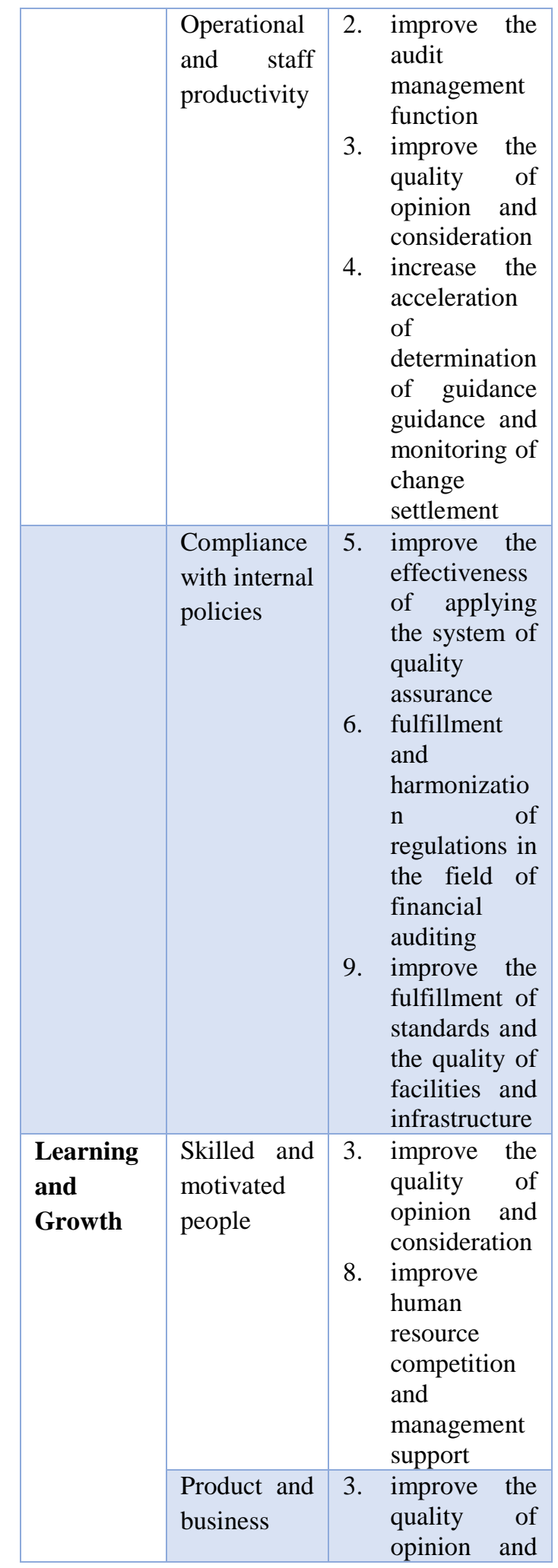


innovation

consideration

culture

To know the level of BSTI capability as a whole, it is necessary to calculate the average value of the whole process of CoBIT Buddhi Dharma University that is:

Capability level $=$

$\frac{(0 \times 0)+(1 \times 0)+(2 \times 33)+(3 \times 1)+(4 \times 0)+(5 \times 0)}{37}=\mathbf{2 . 0 2 7}$

So it can be concluded that the level of BSTI capability is currently at the level of 2027 and is considered the achievement of its capability is still low

\section{CONCLUSION AND FUTURE \\ WORK}

1. From the results of analysis and evaluation by doing assessment on CoBIT 5 shows BSTI (Bureau of Information Systems \& Technology) is currently at level 2 (managed process), with a value of 2.027 . which details there is 1 process at level 3, 33 processes at level 2 and the absence of processes that reach level 4 and 5, being at level 2 means that process performance has been adequately managed for planning, control and adjustment. Work productnya has been run, controlled, managed properly.

2. That Buddhi Dharma University should be able to reach level 3 on the order

3. manage IT. Although IT acts as a supporter, not as a leading role. But with improved IT governance, it can improve internal controls and make it easier for auditors to run their jobs

After conducting research and evaluation on the CoBIT process, it is suggested to be considered for further research and also other IT Bureau in managing IT, that is:

1. Buddhi Dharma University, especially BSTI should pay more attention to the handling and management of risk, thereby reducing risks and controlling risks.

2. In this case, if Buddhi Dharma University focuses solely on achieving level 3 to the extent of applicable standards, Buddhi Dharma POS University in every process In achieving the objective, BSTI embodies the comprehensive and effective Buddhi Dharma IT governance, BSTI better adds capability level with minimum score of 3 on key performance indicators of the objective 


\section{REFERENCES}

Indrajit, Richardus Eko. 2006. Kajian Strategies Analisa Cost-Benefit Investasi Teknologi Informasi. Jakarta.

Institute, IT Governance. 2003. Board Briefing on IT Governance. Illinoise: ISACA.

ISACA. 2012. COBIT 5 A Bussiness Framework for the Governance and Management of Enterprise IT. USA: ISACA.

-. 2012. COBIT 5 Enabling Processes. USA: ISACA.

—. 2012. COBIT 5 Implementation. USA: ISACA.

-. 2010. IT Standards, Guidelines, Tools and Techniques for Audit and Assurance and Control Professionals. USA: ISACA.

—. 2013. Process Assessment Model (PAM):Using COBIT 5. USA: ISACA.

Riki. 2017. "Maturity Level Assessment of IT Governance in Academic Management System. Based on CoBIT 4.0 Framework PO and AI Domain. Case Study STMIK Buddhi." Biannual Postgraduate Seminar 2017. Bestari Jaya: Unisel.

Weill, Peter, and Ross W Jeanne . 2004. IT Gvernance - How to Performers Manage IT Decision Rights for Superior Results. Boston: Harvard Business School Press.

Riki, Riki. (2017). Maturity Level Assessment of IT Governance in Academic Management System. Based on CoBIT 4.0 Framework PO and AI Domain. Case Study STMIK Buddhi. 10.13140/RG.2.2.18462.02887

\section{RIWAYAT HIDUP}

Riki Lulus pada Program Studi Sistem Informasi (S1) di bidang eCommerce Tahun 2006, Program Studi Teknik Informatika (S2) di bidang Sistem Informasi Manajemen. Saat ini sebagai Dosen Tetap pada Program Studi Sistem Informasi, Universitas Buddhi Dharma 